\title{
BEGINNING TEACHER LEARNING IN SCHOOL- UNIVERSITY PARTNERSHIPS: UNDERSTANDING THE COMPLEXITIES OF DEVELOPING BEGINNING-TEACHER KNOWLEDGE IN A PARTNERSHIP SETTING
}

\author{
Brian Marsh ${ }^{*}$
}

\begin{abstract}
Developing beginning-teacher knowledge in a school-university partnership is both complex and messy. This arises from the debates about (1) what beginning teachers should know and relates to the balance between theoretical knowledge and practical knowledge and (2) where that knowledge should be developed. In considering what type of knowledge beginning teachers should acquire and by reviewing partnership discourse particularly from a sociocultural perspective, suggestions are made for supporting effective beginning-teacher learning.
\end{abstract}

Key Words: Activity theory, school-university partnership, teacher development, beginning-teacher learning, teacher knowledge

\section{INTRODUCTION}

This paper is a discussion 'think piece' regarding the complexities of developing teacher knowledge in the context of a school-university partnership. It is a followup to an empirical evaluation of a teacher-development project in a partnership based out of an English university. Although it has a particular location and is influenced by a specific policy context, there are principles that can be applied to such partnerships in many international jurisdictions.

In a previous paper (Marsh, 2019), ${ }^{1}$ I discussed the outcomes of an evaluation of a video-mediated lesson observation project designed to support teacher professional learning and development for both beginning and in-service teachers. It was established by teacher-educators and located in the secondary sector of a school-university partnership in England. The effectiveness of the partnership working was discussed by considering the degree of congruence between the

\footnotetext{
Dr Brian Marsh, BSc, MA, EdD.

1 Marsh, B. 2019. Developing a project within a school-university partnership: factors that influence effective partnership working. Research Papers in Education.
} 
perspectives of and division of labour between both school-based mentors and teacher-educators and those factors identified in literature as supporting effective partnership working. The findings pointed to the effectiveness of the project being compromised when power and control were located within one community resulting in asymmetric power relations and school-based mentor disengagement, and thus the project aims were only partly fulfilled.

In this paper I focus on one aspect of the project, namely beginning-teacher learning. Using this focus I explore and discuss the complexity and messiness of beginning-teacher learning in a partnership context. This paper adds to both the discourses of beginningteacher learning and school-university partnership working. I examine:

1. beginning-teacher learning - what type of knowledge should beginningteachers be acquiring in their initial training

2. school-university partnerships

a. how they are described and characterised - drawing from partnership discourse

b. the complexities of learning in a partnership context - looking the through the lens of sociocultural discourse

\section{BEGINNING-TEACHER KNOWLEDGE}

The foundation for career-long learning is established during the earliest stages of a teacher's career. Beginning teachers need to acquire knowledge, skills and understanding as well as learn how to critically evaluate and improve their own practice during the period of initial teacher education. Stürmer et al. (2012) ${ }^{2}$ indicate that beginning-teacher education programmes should both equip beginning teachers with a declarative knowledge base about effective teaching and support them in applying that knowledge in classroom situations. However, problematising what beginning teachers need to know raises a number of issues and questions:

1. what should comprise the specific content of beginning-teacher learning?

2. how can that content be most effectively delivered in order to best support the development of beginning teachers?

In teacher education there is more urgency about 'what to do' than about 'why' beginning teachers should do it (Ovens, 2000). ${ }^{3}$ One significant consequence is

2 Stürmer, K., Könings, K. \& Seidel, T. 2012. Declarative knowledge and professional vision in teacher education: Effect of courses in teaching and learning. British Journal of Educational Psychology, 83, 467-483.

3 Ovens, P. 2000. Becoming scientific and becoming professional: towards moderating rationalism in the initial teacher education curriculum. Curriculum Journal, 11, 177-197. 
that beginning teachers look for immediate and pragmatic solutions. Nevertheless, Alsop et al. (2005) ${ }^{4}$ argue that locating the specifics of teaching within some broader theoretical framework should be fundamental to the development of teachers. National policy in England (DfE, 2011) ${ }^{5}$ looks at knowledge and expertise in terms of competence and capability within the classroom. While this acknowledges subject and pedagogical knowledge, it omits consideration of the place of educational theory. The content of what beginning teachers should learn is contentious and policy-driven.

Teachers require a vast range of things they should both know and be able to do in order to undertake their work (Darling-Hammond, 2006). ${ }^{6}$ This was outlined in a framework of knowledge, skills and dispositions (Bransford et al., 2005): ${ }^{7}$

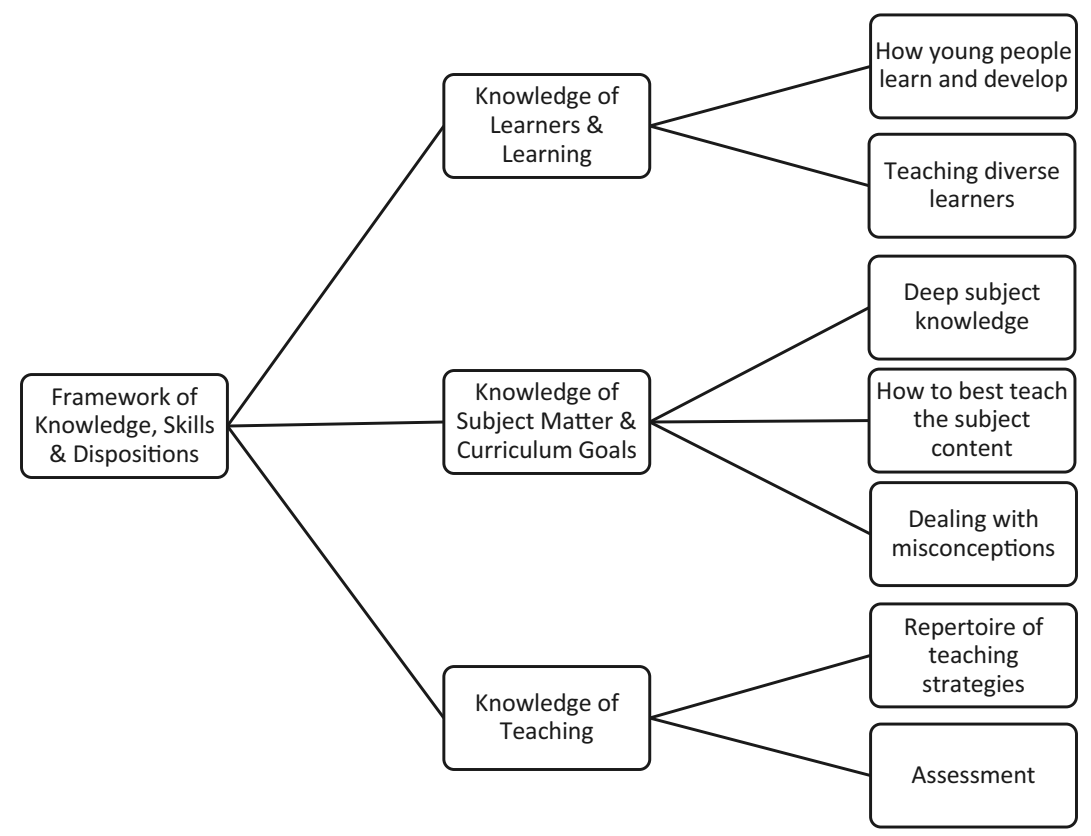

Figure 1: Framework of knowledge, skills and dispositions - Bransford et al. (2005).

\footnotetext{
${ }^{4}$ Alsop, S., Bencze, L. \& Pedretti, E, (eds.) Analysing Exemplary Teaching, Maidenhead Open University Press.

${ }^{5}$ DfE 2011. Teachers' Standards. London: Department for Education.

${ }^{6}$ Darling-Hammond, L. 2006. Constructing 21st-Century Teacher Education. Journal of Teacher Education, 57, 300-314.

7 Bransford, J., Darling-Hammond, L. \& Lepage, P. 2005. Introduction. In: DarlingHammond L., Bransford, J., Lepage, P., Hammerness, K. \& Duffy, H. (eds.) Preparing Teachers for a Changing World: What Teachers Should Learn and Be Able to Do. San Francisco: Jossey-Bass.
} 
Commenting on this framework, Burn et al. $(2015)^{8}$ write:

the range of different aspects that each dimension encompasses and the complex interplay between them make the prospect of trying to get to grips with them a formidable undertaking.

At the heart of the debate are questions about the nature of knowledge and the effects of different kinds of knowledge on teachers and teaching (Loughran, 2006). ${ }^{9}$ Part of the debate surrounds the relationship, and perceived value, of the formal knowledge of teaching (often seen as the province of a Higher Education Institute, HEI) and the practical knowledge of teaching (as created by teachers through their classroom experiences). Teachers in schools put forward their everyday practice and demonstrate the complex and usually tacit knowledge that informs it; but it is also important to note that an appropriate knowledge base of facts, principles and experience is essential for underpinning and justifying the choices and actions they are making.

A useful conceptualisation of teacher knowledge is that originally developed by Shulman (1986)..$^{10} \mathrm{He}$ recognised was that if teachers are to be effective practitioners, they need both an in-depth knowledge of their subject and a comprehensive knowledge and understanding of how to represent this subject knowledge to learners. Shulman (1987) ${ }^{11}$ went on to describe seven categories in what he calls a teachers' knowledge bases:

1. Content knowledge;

2. General pedagogic knowledge;

3. Curriculum knowledge;

4. Pedagogical content knowledge;

5. Knowledge about the learners;

6. Knowledge of educational contexts;

7. Knowledge of educational ends, purposes and values.

${ }^{8}$ Burn, K., Hagger, H. \& Mutton, T. 2015. Beginning Teachers' Learning, Northwich, Critical Publishing.

9 Loughran, J. 2006. Developing a Pedagogy of Teacher Education, London, Routledge.

10 Shulman, L. 1986. Those who understand: knowledge growth in teaching. Educational Researcher, 15, 4-14.

11 Shulman, L. 1987. Theory, practice and the education of professionals. The Elementary School journal. 98.511-526. 
Although conceptualisation of this has evolved since Shulman first articulated this framework, see e.g. Gess-Newsome (2015), ${ }^{12}$ one benefit of Shulman's (1987) thinking is that it offers an opportunity to identify those aspects of knowledge required by a teacher, particularly pedagogical content knowledge. It begins to outline those factors that teachers need to develop. Pedagogical content knowledge incorporates how teachers interpret and transform subject knowledge in the context of supporting pupil learning (Van Driel et al., 1998). ${ }^{13}$ It encompasses an understanding of common learning difficulties and pupil misconceptions. Subject content knowledge is brought to the classroom, whereas pedagogic content knowledge is developed and learned from classroom experience. The two interact and inform each other.

Pedagogical content knowledge is what allows for the meaningful blending of content and pedagogy for teaching.

$(\text { Segall, 2004) })^{14}$

Initially beginning teachers have very limited pedagogical knowledge but rapidly acquire it. They do so through observation and discussion of other teachers' practices (Hagger and McIntyre, 2006) ${ }_{15}^{15}$ collaborative planning and teaching, and focussed support and evaluative feedback on their planning and teaching from teachers in their placement school (Burn, 2007b).${ }^{16}$ Early-career professional learning is characterised by the accumulation of experience, although not all of it is consciously processed. Moreover, as pedagogical knowledge increases, so does the understanding of subject content knowledge (Wellington and Ireson, 2008). ${ }^{17}$ The usefulness of this framework is that it begins to outline those factors that teachers need to develop.

12 Gees-Newsome, J. 2015. A model of teacher professional knowledge and skill including PCK, in: Berry, A. Friedrichsen, P. \& Loughran. J. (eds.) Re-examining pedagogical content knowledge in science education, New York, Routledge.

13 Van Driel, J. H., Verloop, N. \& De Vos, W. 1998. Developing science teachers' pedagogical content knowledge. Journal of Research in Science Teaching, 35, 673-695.

14 Segall, A. 2004. Revisiting pedagogical content knowledge: the pedagogy of content / the content of pedagogy. Teaching and Teacher Eduction, 20, 489-504.

15 Hagger, H. \& McIntyre, D. 2006. Learning Teaching from Teachers: Realising the Potential of School Based Teacher Education. Buckingham, Open University Press

16 Burn, K. 2007b. Professional and identity in a contested discipline: challenges for student teachers and teacher educators. Oxford Review of Education, 33, 445-467.

17 Wellington, J. \& Ireson, G. 2008. Science Learning, Science Teaching, Abingdon, Routledge. 
Whilst there is no universally accepted consensus about which knowledge components are included, the notion of pedagogical content knowledge provides a valuable framework for the discussion of teachers' knowledge and their decisionmaking because it focuses attention on subject-specific knowledge, as well as other categories of knowledge used by teachers (Burn, 2007a, Segall, 2004, Burn, 2007b). However, there are difficulties for trainees seeking to develop pedagogical content knowledge:

1. Kerfoot (2009), ${ }^{18}$ for example, suggests that pedagogical content knowledge is the most demanding to acquire and is only developed over a period of years;

2. Loughran et al. (2004) ${ }^{19}$ note that it is a difficult process to both recognise and articulate. It is an internal construct that is complex and tacit, and time is rarely provided in schools for discussions that enable teachers to describe their tacit professional knowledge in articulated forms;

3. Carlsen (2001) ${ }^{20}$ building on Shulman's work, suggests that these domains of teacher knowledge support consideration of questions such as: 'How might a Biology teacher's knowledge differ from that of a biologist?'

4. Shulman fails to identify which aspects of a teacher's knowledge base are codified and which are implicit.

5. The knowledge bases are not stand-alone dimensions - they are complex and deeply interrelated.

6. PCK is an integrative framework - it doesn't distinguish which teacher knowledge base or component of a teacher knowledge base is best suited for being developed in an HEI setting or in school.

Although Shulman's (1987) typology is useful in identifying those components that comprise a teacher's knowledge base, he does not comment upon either how that knowledge is acquired or where it is acquired. Hall and Andriani (2003) ${ }^{21}$ suggest that tacit knowledge is acquired by experience, the knowledge of what

18 Kerfoot, B. 2009. What is Science Teaching? Who are Science Teachers? In: Liversidge, T., Cochrane, M., Kerfoot, B. \& Thomas, J. (eds) Teaching Science. London, Sage

${ }_{19}$ Loughran, J., Mulhall, P. \& Berry, A. 2004. In search of pedagogical content knowledge in science: developing ways of articulating and documenting professional practice. Journal of Research in Science Teaching. 41, 370-391

${ }^{20}$ Carlsen, W. S. 2001 Domains of Teacher Knowledge. In: Gess-Newsome, J. \& Lederman, N. G. (eds) Examining Pedagogical Content Knowledge: The Construct and its Implications for Science Education. Berlin, Springer.

${ }^{21}$ Hall, R. \& Andriani, P. 2003. Managing knowledge associated with innovation. Journal of Business Research, 2003. 
works, and is characterised by causal ambiguity. Eraut $(2007)^{22}$ argues that there is a large tacit dimension in professional knowledge, which includes routines and understanding the situation, both in preparation and when responding to classroom events.

\section{SCHOOL-UNIVERSITY PARTNERSHIPS}

If problematising the types of knowledge a beginning teacher should develop is contentious, then so is the site where that knowledge is gained.

An important feature in many international contexts for the preparation of beginning teachers are school-university partnerships. As different jurisdictions develop alternative pathways for beginning teachers to enter the teaching profession, such partnerships are subject to change (Marsh, 2019); thus it is well accepted that school-university partnerships are complex and contestable (Douglas, 2012 ${ }^{23}$, Walkington, 2007). ${ }^{24}$ Although school-university partnerships vary in character, Conroy et al. (2013) ${ }^{25}$ identify a key focus for working in the ITE aspect of partnership, namely linking 'knowledge about teaching and learning (academic study) with knowledge of teaching and learning (professional practice knowledge)'.

However, the development of beginning-teacher knowledge in a partnership context is problematic. Cochran-Smith (2003)notes that beginning teachers struggle to apply their knowledge in actual classroom practice. This is supported by Smagorinsky et al. $(2003)^{26}$ and Eraut (2004), ${ }^{27}$ who have indicated that the transfer of knowledge from the HEI setting to the school setting is particularly difficult. Reasons for this include:

${ }^{22}$ Eraut, M. 2007. Learning from other people in the workplace. Oxford Review of Education, 33, 403-422.

${ }^{23}$ Douglas, A. 2012. Capturing the object of initial teacher education by studying toolsin-use in four school subject departments. Research Papers in Education, 27, 285-302.

${ }^{24}$ Walkington, J. 2007. Improving partnerships between schools and universities: professional learning with benefits beyond pre-service teacher education. Teacher Development, 11, 277-294.

${ }^{25}$ Conroy, J., Hulme, M. \& Menter, I. (2013). Developing a 'clinical model' for teacher education. Journal of Education for Teaching, 39,557-573.

${ }^{26}$ Smagorinsky, P., Cook, L. \& Johnson, T. 2003. The twisting path of concept development in learning to teach. Teachers College Record, 105, 1399-1436.

${ }^{27}$ Eraut, M. 1994. Developing Professional Knowledge and Competence, London, Falmer Press. 
1. The abstract or uncontextualized nature of theoretical concepts presents difficulties for the teacher-educator attempting to provide illustrations or examples of such concepts for beginning teachers with little recent experience of schools.

2. The situated nature of learning (Brown et al., 1989). ${ }^{28}$ The association by beginning teachers of educational theory with the university and teaching practice with the school can be seen in terms of the divergence of two communities of practice (Wenger, 1999,i Smagorinsky et al., 2003); what Eraut (1994) describes as institutional separation. This to some extent, mirrors the physical separation experienced by the two sets of practitioners.

\section{(a) Characteristics of School-University Partnerships}

Adamson and Walker (2011) ${ }^{29}$ describe partnership collaboration as messy insomuch as it is unpredictable, complex and difficult to both monitor and manage with often unresolved issues and different perceptions of what teaching involves (Fancourt et al., 2015).$^{30}$ Moreover, there is recognition (Kruger et al., 2009, Cope and Stephen, 2001) $)^{31}$ that schools and universities have conflicting agendas and often have radically different purposes, which are reflected in both their activities and micro-politics.

The current relationships between schools and universities in England are shaped by a policy-led framework, which privileges schools over HEIs, and a performativity culture characterised by standards, inspection and regulation (Hutchinson, 2011). ${ }^{32}$ Partnerships, according to Bloomfield and Nguyen (2015), ${ }^{33}$ are constructed and contested in the milieu of political rhetoric, policy

28 Brown, J., Collins, A. \& Duguid, P. 1989. Situated cognition and the culture of learning. Educational Researcher, 18, 32-42.

29 Adamson, B. \& Walker, E. 2011. Messy collaboration: learning from a learning study. Teaching and Teacher Education, 27, 29-36.

${ }^{30}$ Fancourt, N., Edwards, A. \& Menter, I. 2015. Reimagining a school-university partnership: the development of the Oxford Deanery narrative. Education Inquiry, 6, 353-373.

31 Cope, P. \& Stephen, C. 2001. A role for practising teachers in initial teacher education. Teaching and Teacher Education, 17, 913-924.

${ }^{32}$ Hutchinson, S. 2011. Boundaries and bricolage: examining the roles of universities and schools in student teacher learning. European Journal of Teacher Education, 34, 177-191.

33 Bloomfield, D. \& Nguyen, H. T. 2015. Creating and sustaining professional learning partnerships: activity theory as an analytical tool. Australian Journal of Teacher Education, 40,23-44 


\section{THE BUCKINGHAM JOURNAL OF EDUCATION}

(both national and local) and grassroots practice. The questions that arise from this include:

1. Can partnerships be one of equals?

2. How is teacher learning shaped in contested orientations?

3. To what extent are schools and universities effective sites for teacher learning?

Quinlivan et al. (2008) ${ }^{34}$ point to there being much descriptive, yet often uncritical, literature about school-university partnerships. Where problematisation does exist, the focus tends to be on observable practices (e.g. Day, 1998) ${ }^{35}$ or relational perspectives (e.g. Furlong et al., 2000). ${ }^{36}$ Little is considered from a pedagogical and teacher-learning perspective (Mutton, 2016, Callahan and Martin, 2007). ${ }^{37}$

Addressing this an interpretive framework for analysing school-university partnerships (Marsh, 2019) is shown in Table 1. It draws together the different perspectives identified in school-university partnership literature. While there is no implication that any one strand cannot be more or less developed than the other two it finds its value, in tandem with much partnership discourse, in affording an interpretive framework that can be used to describe aspects of partnership working. Nevertheless, this model indicates some of the complexities of working within a partnership network. This is consistent with Mutton and Butcher (2008), ${ }^{38}$ who write that there is emerging evidence that schools are extending their notion of partnership from solely ITE to a multi-level position involving overlapping communities of practice concerned with some aspects of professional learning, CPD and research (Callahan and Martin, 2007, Edwards, 1997). ${ }^{39}$

${ }^{34}$ Quinlivan, K., Boyask, R. \& Carswell, S. 2008. Dynamics of power and participation in school-university partnerships. New Zealand Journal of Educational Studies, 43, 65-83.

35 Day, C. 1998. Re-thinking School-University Partnerships: A Swedish Case Study Teaching and Teacher Education, 14, 807-820.

36 Furlong, J., Barton, L., Miles, S., Whiting, C. \& Whitty, G. 2000. Teacher Education in Transition - Reforming Professionalism?, Buckingham, Open University.

37 Mutton, T. 2016. Partnership in Teacher Education. In: Group, T. T. E. (ed.) Teacher Education in Times of Change. Bristol: Policy Press. Callahan, J. \& Martin, D. 2007. The spectrum of school university partnerships: a typology of organisational learning systems. Teaching and Teacher Education, 23, 136-145.

38 Mutton, T. \& Butcher, J. 2008. 'We will take them from anywhere': schools working within multiple initial teacher training partnerships. Journal of Education for Teaching, 34, 45-62.

39 Ewards, A. 1997. Possible futures for initial teacher training in the primary phase. In: Hudson, A. \& Lambert, D. (eds.) Exploring futures in initial teacher education. London: Institute of Education. 
Table 1: Interpretive framework for analysing school-university partnerships from Marsh (2019)

\begin{tabular}{|c|c|c|c|c|}
\hline & $\begin{array}{l}\text { Institutional } \\
\text { Separation }\end{array}$ & & \begin{tabular}{|l|} 
Contrived \\
Collegiality
\end{tabular} & $\begin{array}{l}\text { Partnership Becoming } \\
\text { a Professional Learning } \\
\text { Community }\end{array}$ \\
\hline $\begin{array}{l}\text { Partnership } \\
\text { Relationships }\end{array}$ & $\begin{array}{l}\text { HEI or School Led } \\
\text { - characterised by } \\
\text { power and control } \\
\text { - leadership of } \\
\text { programme } \\
\text { resides with one } \\
\text { partner (usually } \\
\text { HEI) } \\
\text { - hierarchy of } \\
\text { relationships } \\
\text { - minimal reciprocity } \\
\text { - unequal expert- } \\
\text { client relationship }\end{array}$ & $\rightarrow$ & $\begin{array}{l}\text { Complementary I } \\
\text { Parallel Working } \\
\text { - HEls organise } \\
\text { overall } \\
\text { programme } \\
\text { - roles of HEI and } \\
\text { schools are } \\
\text { separate but } \\
\text { complementary }\end{array}$ & $\begin{array}{l}\text { Collaborative } \\
\text { - whole programme is } \\
\text { jointly planned and } \\
\text { delivered } \\
\text { - schools and universities } \\
\text { work together in an } \\
\text { integrated multi-level } \\
\text { fashion involving ITE, } \\
\text { CPD and research } \\
\text { - both educators and } \\
\text { school-based mentors } \\
\text { seen as having } \\
\text { complimentary } \\
\text { expertise } \\
\text { - trust and mutuality } \\
\text { - distributed leadership } \\
\text { - reciprocity }\end{array}$ \\
\hline $\begin{array}{l}\text { Observable } \\
\text { Practice }\end{array}$ & $\begin{array}{l}\text { Traditional } \\
\text { - programme } \\
\text { designed by HEI } \\
\text { for implementation } \\
\text { in both HEI and } \\
\text { schools } \\
\text { - fragmentation } \\
\text { - lack of connection } \\
\text { between school- } \\
\text { based and } \\
\text { university } \\
\text { experiences }\end{array}$ & $\rightarrow$ & $\begin{array}{l}\text { Developing } \\
\text { - focus is usually } \\
\text { on one partner's } \\
\text { needs } \\
\text { - but benefits and } \\
\text { value for all }\end{array}$ & $\begin{array}{l}\text { Transformative } \\
\text { - both teacher educators } \\
\text { and school-based } \\
\text { mentors were seen by } \\
\text { each other as having } \\
\text { complementary } \\
\text { expertise } \\
\text { - joint responsibility for } \\
\text { agreed practices and } \\
\text { outcomes } \\
\text { - congruence of purpose } \\
\text { between partners }\end{array}$ \\
\hline $\begin{array}{l}\text { Pedagogical } \\
\text { Framework }\end{array}$ & $\begin{array}{l}\text { Theory-Practice } \\
\text { Gap } \\
\text { - classroom practice } \\
\text { knowledge and } \\
\text { codified evidence } \\
\text { informed } \\
\text { knowledge } \\
\text { perceived as } \\
\text { separate } \\
\text { - disconnect } \\
\text { between learning } \\
\text { in school and } \\
\text { learning in HEI }\end{array}$ & $\rightarrow$ & $\begin{array}{l}\text { Reflection on } \\
\text { Practice } \\
\text { - beginning } \\
\text { teacher learning } \\
\text { is driven by } \\
\text { simple reflective } \\
\text { questioning of } \\
\text { "how can I do } \\
\text { this better" } \\
\text { - limited } \\
\text { interpretation of } \\
\text { practice in terms } \\
\text { of theory }\end{array}$ & $\begin{array}{l}\text { Shared Understandings } \\
\text { - of what beginning } \\
\text { teachers need to learn } \\
\text { - of how they might learn } \\
\text { - of best site for learning } \\
\text { - practice of theory and } \\
\text { theorising of practice } \\
\text { - pedagogy of beginning } \\
\text { teacher education } \\
\text { developed and shared } \\
\text { between school-based } \\
\text { mentors and teacher } \\
\text { educators }\end{array}$ \\
\hline
\end{tabular}




\section{(b) The Complexities of Learning in a Partnership Context - A Sociocultural Perspective}

While partnership discourse affords a descriptive perspective of how beginning-teacher knowledge is developed in partnerships an explanatory lens can be drawn from sociocultural perspectives of learning. Thus partnerships are considered by e.g. (Tsui et al., 2009b) ${ }^{40}$ in terms of communities of practice and by Douglas $(2014)^{41}$ in terms of activity theory. These two perspectives afford reflection on the processes involved in rather than just the outcomes of partnership working (Edwards et al., 2002). ${ }^{42}$

One key concept for thinking about learning is the 'community of practice', where consideration is given to how knowledge is used and shared in communities of practitioners (Lave and Wenger, 1991). ${ }^{43}$ These communities are (1) schoolbased and at secondary level are also subject-based and (2) university-based. They are shaped by the rules and emergent practices of their respective systems. Wilson $(2004)^{44}$ develops this and argues that activity theory locates such production of knowledge in the context of practice. Knowledge, both conceptual propositional knowledge and experiential craft knowledge is embedded in action, it is often tacit and not easily accessible. New members (in this case beginning teachers) are introduced to this knowledge through 'legitimate peripheral participation' alongside more experienced practitioners. Thus, for Wilson activity theory offers a structure for examining:

1. The complex working relationships between schools and universities

2. Relationships at a level of individuals, institutional structures and rules

Cultural-historical activity theory and the concept of expansive learning

40 Tsui, A., Lopez-Real, F. \& Edwards, G. 2009b. Sociocultural Theories of Learning Revisited. In: Tsui, A., Edwards, G. \& Lopez-Real, F. (eds.) Learning in School-University Partnerships. Abingdon: Routledge.

41 Douglas, A. 2014. Student teachers in school practice: An analysis of learning opportunities, Basingstoke, Palgrave Macmillon.

42 Edwards, A., Gilroy, P. \& Hartley, D. 2002. Rethinking Teacher Education, London, RoutledgeFalmer.

${ }^{43}$ Lave, J. \& Wenger, E. 1991. Situated Learning: legitimate peripheral participation, Cambridge, Cambridge University Press.

44 Wilson, E. 2004. Using activity theory as a lens to analyse interaction in a universityschool initial teacher education and training partnership. Educational Action Research, $12,587-612$. 
provides a lens through which to examine at a systemic level the development of partnership working with a view to considering the differences and contradictions between the communities involved in the partnership (Hutchinson, 2011). It provides an analytical framework whereby the complexities of relationships and identities between individuals, communities and organisations might be considered and understood (Bloomfield and Nguyen, 2015, Wilson, 2004). Philpott (2014) (5 $^{4}$ notes that cultural-historical activity theory can be used to consider how activity systems can shape learning.

Tsui et al. $(2009 \mathrm{a})^{46}$ make two key points concerning activity systems:

1. they are dynamic and subject to change

2. by participating in meaningful activities an individual appropriates the cultural tools of language, behaviour and norms. This, they argue, is transformational and is where learning occurs

Figure 3 is the diagrammatic form of a second-generation activity system developed for school-university partnership working:

The subject represents beginning teachers undertaking ITE with the object being a growth and development of professional knowledge and a transformation in practice.

Holt and Morris (1993) ${ }^{47}$ note the importance of mediational instruments, tools and artefacts within an activity system. They are the means that mediate the subject's activity towards the object. Moreover, they are at the apex of the subsystem which, according to Jonassen (2000), ${ }^{48}$ is the most important subsystem in bringing about transformation and change. Wilson (2004) adds that 'the "owners" of the instruments are controllers of the system'. This has implications (see Table 1) in terms of:

1. the power dynamics within the partnership, i.e. whether there is institutional separation with one partner dominating or a genuine professional learning community,

\footnotetext{
45 Philott, C. 2014. Theories of Professional Learning, Northwich, Critical Publishing.

46 Tsui, A., Lopez-Real, F. \& Eedwards, G. 2009a. Sociocultural Perspectives of Learning. In: Tsui, A., Edwards, G. \& Lopez-Real, F. (eds.) Learning in School-University Partnership. London: Routledge.

47 Holt, R. \& Morris, A. 1993. Activity theory and the analysis of organisations. Human Organisation, 52, 97-109.

48 Jonassen, D. 2000. Learnin; as activity. AECT Convention, Denver.
} 


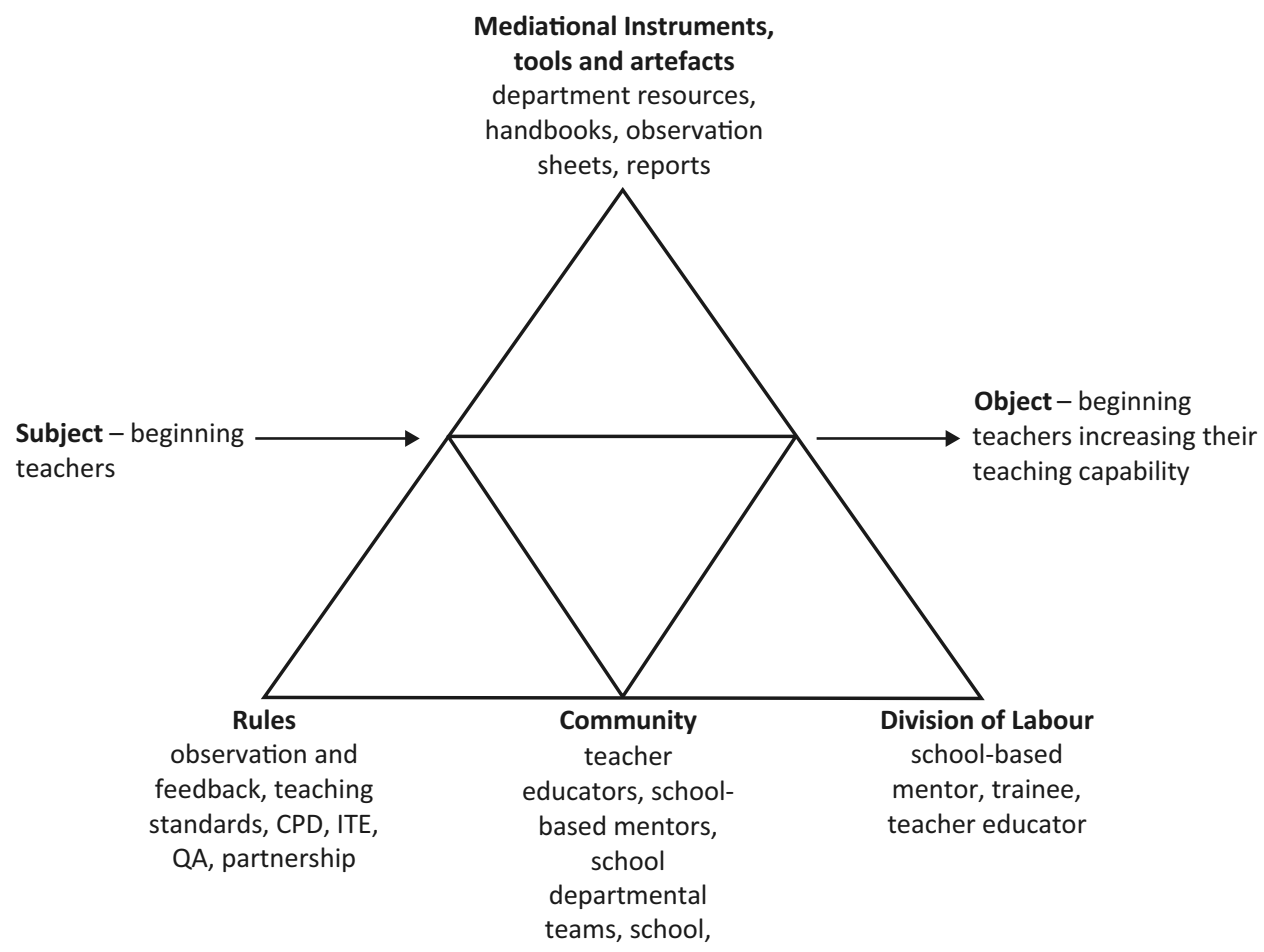

Figure 2: A Second-Generation Activity System for School-University Partnership Working.

2. the nature of knowledge development, i.e. the potential of a disconnect between learning in school and learning in the HEI or the pedagogy of beginning-teacher education being a shared activity between schools and their partner HEIs.

Central to the activity system is the link between the subject, object and the community involved in supporting the intended goal of transformation of practice. Achieving this change requires energy and resources from both subject and community. The community comprises individuals/groups that focus some of their effort on the object and in terms of school-university partnerships includes the teacher-educators and school-based mentors. Jonassen (2000) notes that this a place of contradictions, as members are simultaneously members of other independent or overlapping activity groups and communities of practice with different intentions. As Douglas (2014) notes, the overall activity is seen differently if colleagues are working with different motives. Related to this are the 
rules and the related division of labour - all part of the community activity. This, too, is a place of contradictions when expectations are perceived differently by he school-based mentors and teacher-educators.

Wilson (2014) ${ }^{49}$ helpfully considers the nature of community in schooluniversity partnerships. If the community practice is embedded in the classroom, then the goals of that community are curriculum coverage and pupil performance. Consequently, the object is unlikely to be the trainee teacher but is more likely to be pupil achievement. This is often the focus of the school-based mentors. If, however, the community is the training partnership, then the object is more likely to be the trainee teachers and their learning outcomes. This often is the focus of the teacher-educators.

A consideration of a third-generation activity system (shown in Figure 3) allows for further clarity. There are a number of similarities between school and university activity systems, yet there are important differences, particularly in terms of community. A third generation of activity system, as proposed by Engeström (2001), ${ }^{50}$ has its focus on the relationship between interacting activity systems, as it is at the intersection of the different systems that there is rich potential for learning.

It is in the interaction of the boundaries where effective teacher learning occurs. As Tsui et al. (2009a) write,

The dynamics of the interaction between the elements within an activity system and between two activity systems and the contradictions so generated are particularly relevant to the understanding of a school-university partnership which is inherently conflictual because schools and universities are rooted in different sociocultural contexts.

However, activity theory alone only hints at the dynamics within that zone. An adaptation of a framework linking communities and networks of practice developed by Handley et al. (2007) ${ }^{51}$ is used to explore the findings. This is

\footnotetext{
49 Wilson, V. 2014. Examining teacher education through cultural-historical activity theory. Tean Journal, 6, 20-29.

50 Engeström, Y. 2001. Expansive learning at work. Journal of Education and Work, 14, 133-156.

51 Handley, K., Clark, T., Fincham, R. \& Sturdy, A. 2007. Researching situated learning: participation, identity and practices in client-consultant relationships. Management Learning, 38, 173-191.
} 


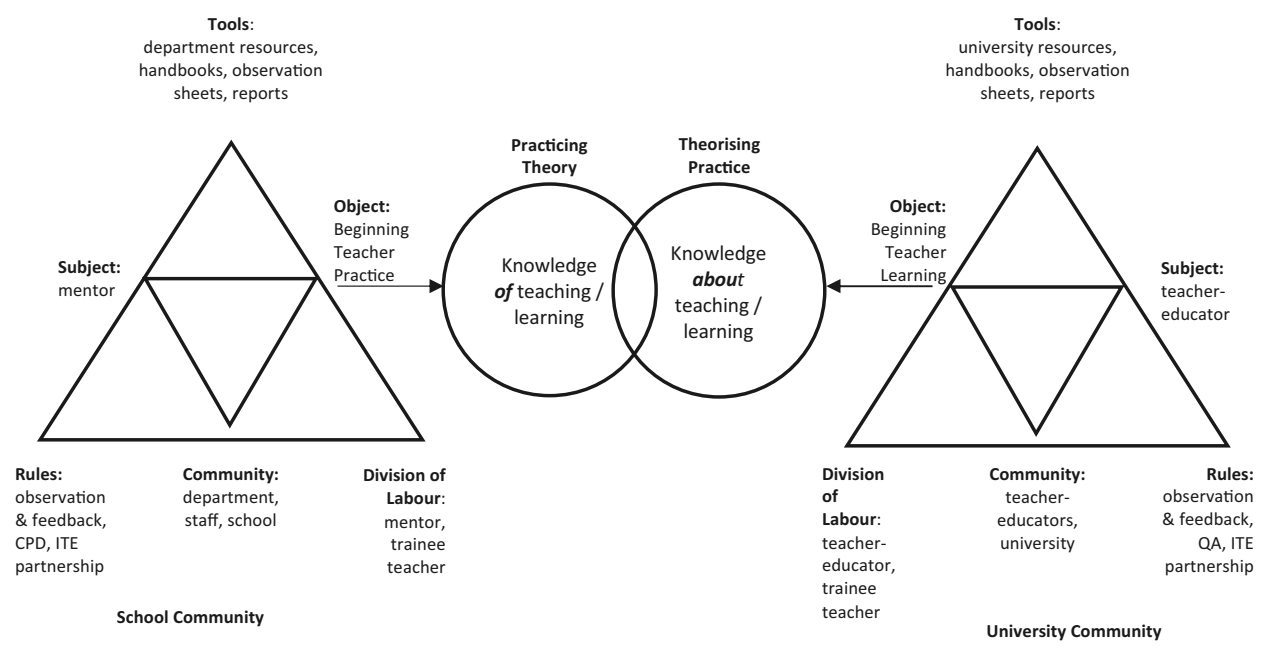

Figure 3: A Third-Generation Activity System for Beginning Teacher Education.

consistent with Edwards (2005), ${ }^{52}$ and Hodkinson and Hodkinson (2004) ${ }^{53}$ conceptualise such communities as fields involving overlapping levels of participation. A characteristic of such fields is that they are organised and differential (Martin, 2003). ${ }^{54}$ The position of participants is a result of a vector of forces, which, in this model are the influences of power, conflict and competing agendas. This is helpful in adding a focus to the cultures where practice, and in this context professional learning, occurs. This is modelled this in Figure 4. By adapting this model, it is possible to consider the complexities of developing beginning-teacher knowledge within a partnership network by exploring the constructs of participation, identity and practice.

A school-university partnership is subject to the power relations between partner schools and the university. This is, in part, due to their different foci. These foci can, according to Wenger (1998), ${ }^{55}$ facilitate increased collaboration and

52 Edwards, A. 2005. Let's get beyond community and practice: the many meanings of learning by participating. Curriculum Journal, 16, 49-65.

${ }^{53}$ Hodkinson, P. \& Hodkinson, H. 2004. Individuals, communities of practice and the policy context: school teachers' learning in their workplace. Studies in Continuing Education, 25, 3-21.

54 Martin, J. L. 2003. What is field theory? American Journal of Sociology, 109, 1-49.

55 Wenger, E. 1998. Communities of practice: Learning, meaning and identity, Cambridge, Cambridge University Press. 


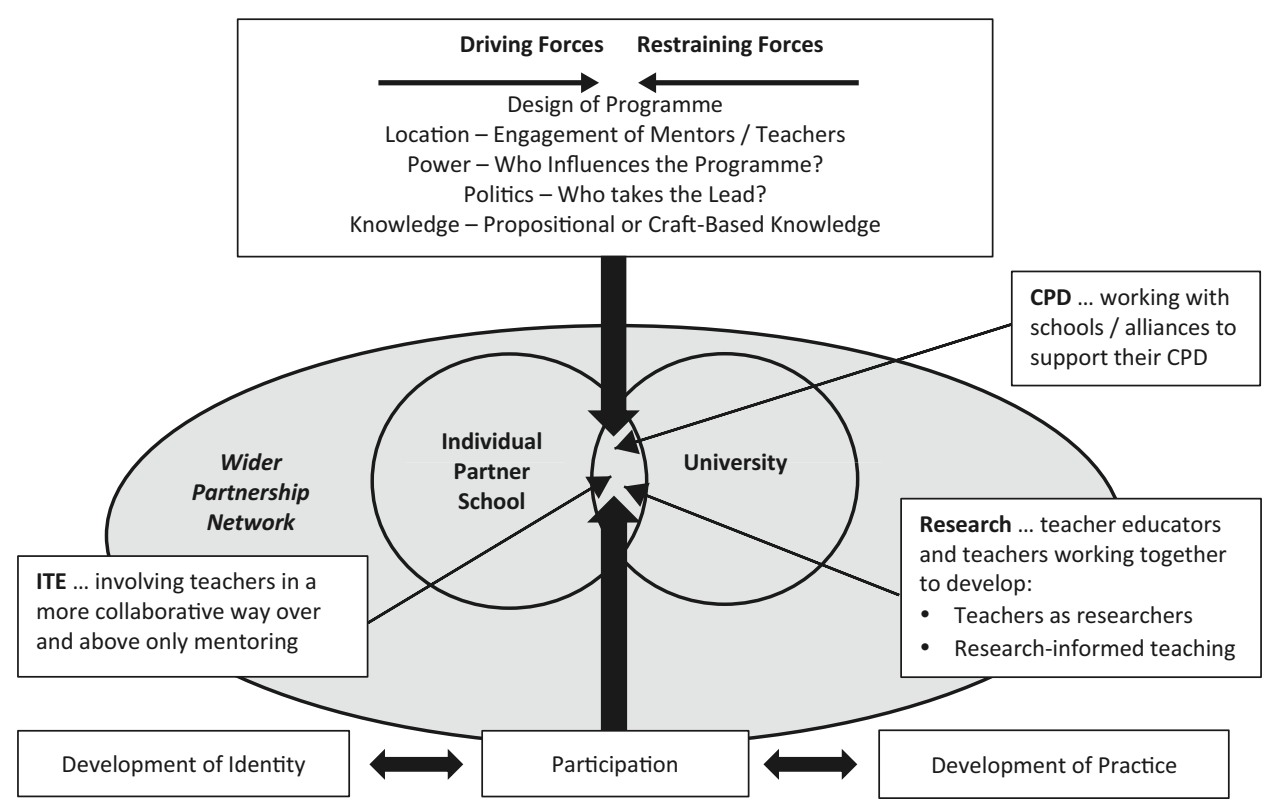

Figure 4: Factors Influencing Partnership Working

cooperation, but they can also be tools for domination. It is at the intersection of the communities of practice that there is rich potential for learning. However, these are contested areas, due to different levels of participation and differential power between the overlapping communities. The challenges of partnership working is considered by Grenfell (2006), ${ }^{56}$ who, looking at social capital within school-university partnerships both in the UK and USA, notes that institutions prioritise their own goals over those arising from partnership working, and institutional dynamics sometimes thwart partnership working.

A further perspective is discussed by Handley et al. (2007), who link communities of practice with the wider network of practice. This is useful in that this model helps identify:

- Overlapping fields of participation

- Communities where practice occurs

56 Grenfell, M. 2006. Bourdieu: Educational explorations in field theory. British Educational Research Association Annual Conference. Warwick. 
- Actors in relationship with one another, along with the comparative interests, influences and power each may have.

This framework is centred on a situated understanding of learning which focuses on the relationships between participation and both their developing identities and practice (Lave and Wenger, 1991). Identity is described as understanding 'who we are and what potential we have' (Handley et al., 2007), whereas practice is considered as social practice, in this case the enactment of teaching.

A combination of the frameworks is seen in Figure 5

It is at the intersection of the communities of practice that there is rich potential for learning. Hutchinson (2011) notes that activity theory and the concept of expansive learning provide a framework for identifying differences and contradictions at a systemic level. Contradictions are those structural tensions both

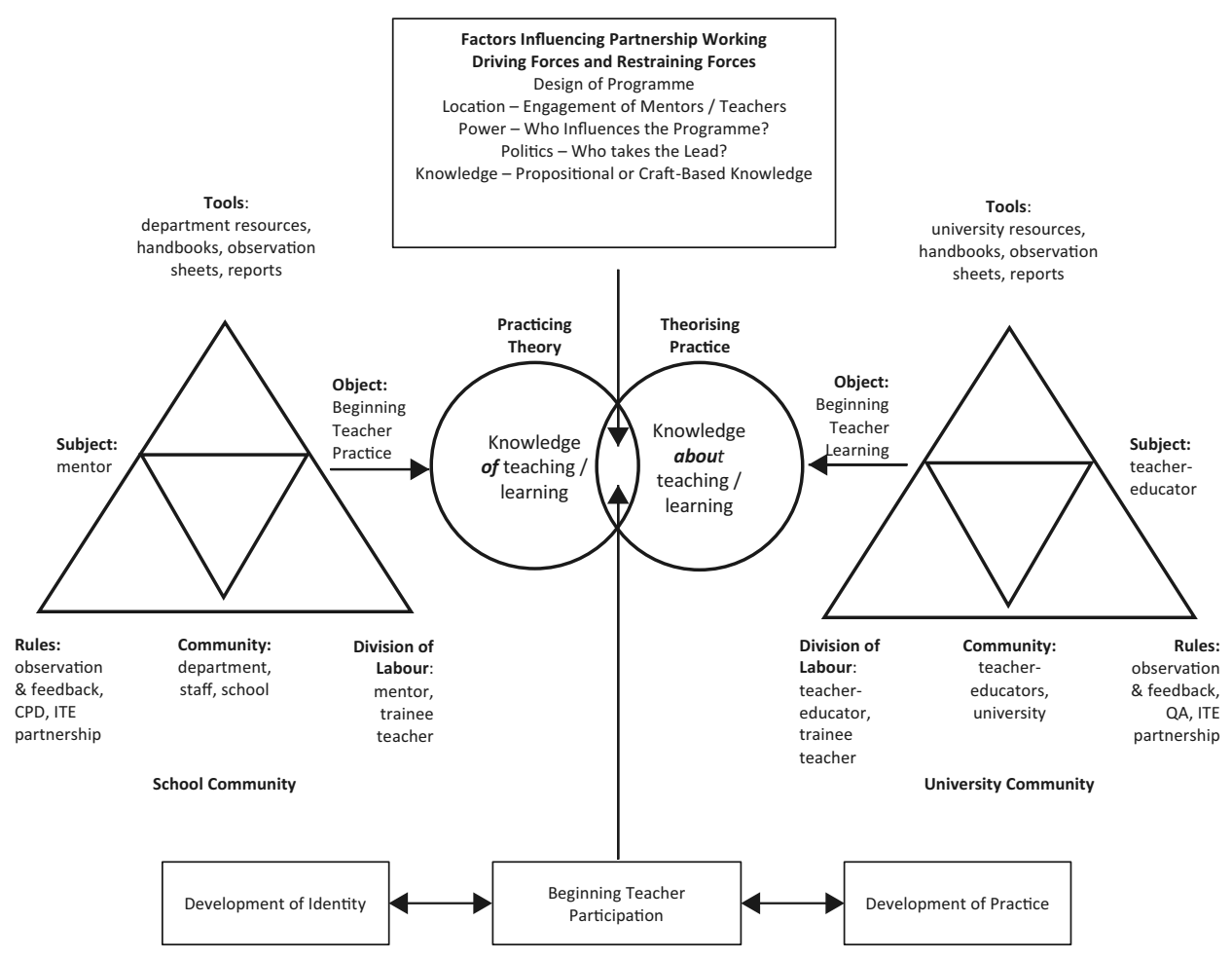

Figure 5: A Third-Generation Activity System including Features of Situated Learning. 
within and between activity systems (Engeström, 1999). ${ }^{57}$ Moreover, he writes that learning encounters occur through contradictions within systems or as in the consideration of this paper between activity systems which represent different communities shaped by their own rules and emergent practices.

\section{CONCLUSION}

The complexities of developing beginning-teacher knowledge in a school-university partnership are compounded by:

1. the debates about what should beginning teachers know, whether teaching is a craft or an evidence-informed profession and who is best placed to deliver such knowledge. An example of this is the discussion surrounding the Initial Teacher Training Content in England (DfE, 2019), ${ }^{58}$

2. the current relationships between schools and universities (particularly in England) are shaped by cultures of performativity characterised by standards, inspection and regulation (Hutchinson, 2011).

Arising from these complexities are questions such as:

1. what is the nature of the partnership - is it one of equals? Using the interpretive framework (Table 1), is it one of institutional separation where there is asymmetry of power or is one of a professional learning community?

2. how is beginning-teacher learning shaped in these contested orientations? Is there a disconnect between the knowledge developed in schools with the knowledge developed in HEIs?

3. to what extent are both the school or the HEI appropriate sites for learning?

Hutchinson (2011) argues that successful partnership working involves exploiting the differences in perspectives between schools and universities, which in turn leads to a transformative approach to both ITE and CPD so potentially affording improvements in teacher learning. Such interactions are, however, challenging. It entails different ways of thinking about practice and a willingness

57 Engeström, Y. 1999. Innovative learning in work teams: analysing cycles of knowledge creation in practice. In: Engeström, Y., Miettinen, R. \& Punamaki-Gital, R. (eds.) Perspectives on Activity Theory. Cambridge: Cambridge University Press.

58 DfE 2019. ITT Core Content Framework. In: EDUCATION, D. F. (ed.). London: Department for Education. 
to open up practice. Further he argues for greater equality in the relationships between school-based mentors, teacher-educators and the beginning teacher.

Akkerman and Bakker (2011) ${ }^{59}$ call for efforts to be made in order to establish interaction across different practices - namely the crossing of boundaries. Mechanisms for doing so include:

1. reviewing practices and coming to shared understandings of how they work and where they are best situated. This requires partnership working to become a professional learning community working together (Marsh, 2019), such that it is collaborative, transformative and has shared understandings of beginningteacher learning.

2. looking for ways of co-ordinating practice, e.g.

a. Mentoring, of beginning teachers which is non-judgemental and developmental and peer-coaching of school-based mentors and teacher educators

b. practice that amplifies the practice of theory and theorising of practice. For teacher-educators this could be e.g. using video of lessons, both synchronously and asynchronously to exemplify theory (Marsh and Mitchell, 2014) ${ }^{60}$ thus grounding theory in what the beginning teachers observe when on practicum. For school-based mentors it could be explanation of classroom practice in terms of evidence-informed practice. In this way the boundary-crossing mechanism of developing professional vision (Stürmer et al., 2012, Seidel et al., 2011) ${ }^{61}$ incorporating noticing and knowledge-based reasoning can be established.

c. sharing of the tools used in each system.

That developing beginning-teacher knowledge in a partnership setting is complex is not contested - but the complexities are not insurmountable, although further work is needed in learning how to respond to them (Hutchinson, 2011). As Stürmer et al. (2012) found that programmes based in universities do enhance teaching-relevant knowledge and skills with particularly with video-based support

59 Akkerman, S. \& Bakker, A. 2011. Boundary crossing and boundary objects. Review of Educational Research, 81, 132-169.

${ }^{60}$ Marsh, B. \& Mitchell, N. 2014. The role of video in teacher professional development. Teacher Development, 18, 403-417.

${ }^{61}$ Seidel, T., Stürmer, K., Blomberg, G., Kobarg, M. \& Schwindt, K. 2011. Teacher learning from analysis of videotaped classroom situations: does it make any difference whether teachers observe their own teaching or that of others? Teaching and Teacher Education, 27, 259-267. 
that focussed on effective teaching. Burn et al. (2015) note the importance of the school-based component, but also recognise that school-based mentors and teacher-educators can work effectively together to develop the professional learning exemplary teaching requires. Essential to this is a shared understanding and outworking of a pedagogy of beginning-teacher education. 